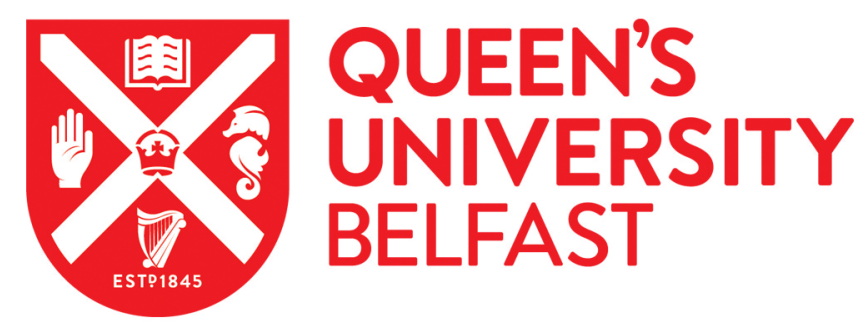

\title{
A revised age for the Kawakawa/Oruanui tephra, a key marker for the Last Glacial Maximum in New Zealand
}

\author{
Vandergoes, M. J., Hogg, A. G., Lowe, D. J. L., Newnham, R. M., Denton, G. H., Southon, J., Barrell, D. J. A., \\ Wilson, C. J. N., McGlone, M. S., Allan, A. S. R., Almond, P. C., Petchey, F., Dabell, K., Dieffenbacher-Krall, A. \\ C., \& Blaauw, M. (2013). A revised age for the Kawakawa/Oruanui tephra, a key marker for the Last Glacial \\ Maximum in New Zealand. Quaternary Science Reviews, 74, 195-201. \\ https://doi.org/10.1016/j.quascirev.2012.11.006 \\ Published in: \\ Quaternary Science Reviews
}

Document Version:

Early version, also known as pre-print

Queen's University Belfast - Research Portal:

Link to publication record in Queen's University Belfast Research Portal

\begin{abstract}
General rights
Copyright for the publications made accessible via the Queen's University Belfast Research Portal is retained by the author(s) and / or other copyright owners and it is a condition of accessing these publications that users recognise and abide by the legal requirements associated
\end{abstract} with these rights.

Take down policy

The Research Portal is Queen's institutional repository that provides access to Queen's research output. Every effort has been made to ensure that content in the Research Portal does not infringe any person's rights, or applicable UK laws. If you discover content in the Research Portal that you believe breaches copyright or violates any law, please contact openaccess@qub.ac.uk. 


\title{
A revised age for the Kawakawa/Oruanui tephra, a key marker for the Last Glacial Maximum in New Zealand
}

\author{
Marcus J. Vandergoes ${ }^{\mathrm{a}, \mathrm{j}, *}$, Alan G. Hogg ${ }^{\mathrm{b}}$, David J. Lowe ${ }^{\mathrm{c}}$, Rewi M. Newnham ${ }^{\mathrm{d}}$, George H. Denton ${ }^{\mathrm{e}}$, \\ John Southon $^{\mathrm{f}}$, David J.A. Barrell ${ }^{\mathrm{g}}$, Colin J.N. Wilson ${ }^{\mathrm{d}}$, Matt S. McGlone ${ }^{\mathrm{h}}$, Aidan S.R. Allan ${ }^{\mathrm{d}}$, \\ Peter C. Almond ${ }^{\mathrm{i}}$, Fiona Petchey ${ }^{\mathrm{b}}$, Kathleen Dabell ${ }^{\mathrm{b}}$, Ann C. Dieffenbacher-Krall ${ }^{\mathrm{j}}$, Maarten Blaauw ${ }^{\mathrm{k}}$ \\ ${ }^{a}$ GNS Science, PO Box 30-368, Lower Hutt 5040, New Zealand \\ ${ }^{\mathrm{b}}$ Radiocarbon Dating Laboratory, University of Waikato, Private Bag 3105, Hamilton 3240, New Zealand \\ ${ }^{c}$ Department of Earth and Ocean Sciences, University of Waikato, Private Bag 3105, Hamilton 3240, New Zealand \\ ${ }^{\mathrm{d}}$ School of Geography, Environment and Earth Sciences, Victoria University of Wellington, PO Box 600, Wellington 6140, New Zealand \\ ${ }^{\mathrm{e}}$ Department of Earth Sciences \& Climate Change Institute, University of Maine, Orono, ME 04469, USA \\ ${ }^{\mathrm{f}}$ Earth System Science Dept, University of California, Irvine, CA 92697-3100, USA \\ ${ }^{\mathrm{g}}$ GNS Science, Private Bag 1930, Dunedin 9054, New Zealand \\ ${ }^{\mathrm{h}}$ Landcare Research, PO Box 40, Lincoln 7640, New Zealand \\ ${ }^{\mathrm{i}}$ Soil and Physical Sciences Department, Lincoln University, PO Box 84, Lincoln 7647, New Zealand \\ ${ }^{\mathrm{j}}$ Climate Change Institute, University of Maine, Orono, ME 04469, USA \\ ${ }^{\mathrm{k}}$ School of Geography, Archaeology and Palaeoecology, Queen's University Belfast, Belfast, Northern Ireland BT7 1NN, UK
}

\section{A R T I C L E I N F O}

\section{Article history:}

Received 5 June 2012

Received in revised form

18 October 2012

Accepted 13 November 2012

Available online $\mathrm{xxx}$

\section{Keywords:}

Last Glacial Maximum (LGM)

Isochron

Kawakawa/Oruanui tephra

Oruanui eruption

Paleoclimate

Tephrochronology

Chronostratigraphy

${ }^{14} \mathrm{C}$ dating

New Zealand

NZ climate event stratigraphy

Southwest Pacific

Marine reservoir ages

\begin{abstract}
A B S T R A C T
The Kawakawa/Oruanui tephra (KOT) is a key chronostratigraphic marker in terrestrial and marine deposits of the New Zealand (NZ) sector of the southwest Pacific. Erupted early during the Last Glacial Maximum (LGM), the wide distribution of the KOT enables inter-regional alignment of proxy records and facilitates comparison between NZ climatic variations and those from well-dated records elsewhere. We present 22 new radiocarbon ages for the KOT from sites and materials considered optimal for dating, and apply Bayesian statistical methods via OxCal4.1.7 that incorporate stratigraphic information to develop a new age probability model for KOT. The revised calibrated age, \pm 2 standard deviations, for the eruption of the KOT is $25,360 \pm 160 \mathrm{cal}$ yr BP. The age revision provides a basis for refining marine reservoir ages for the LGM in the southwest Pacific.
\end{abstract}

Published by Elsevier Ltd.

\section{Introduction}

The Kawakawa/Oruanui tephra (KOT), a widespread product of the Oruanui super-eruption $\left(\sim 530 \mathrm{~km}^{3}\right.$ volume, dense-rock equivalent) from Taupo volcano in New Zealand, is a key chronostratigraphic marker within Last Glacial Maximum (LGM) sediments (e.g. Pillans et al., 1993; Wilson, 2001; Lowe et al., 2008,

\footnotetext{
* Corresponding author. GNS Science, PO Box 30-368, Lower Hutt 5040, New Zealand. Tel.: +64 4 5704541; fax: +64 45704603.

E-mail address: m.vandergoes@gns.cri.nz (M.J. Vandergoes).
}

2010). An accurate and precise age for this isochron enables meaningful comparisons between sequences containing the tephra and independently-dated records beyond its dispersal, or in localities where it was not deposited or is not preserved. Leads or lags of climate response identified on the basis of such comparisons provide important insights into functioning of the climate system at regional, hemispheric and global scales.

More than 60 published ${ }^{14} \mathrm{C}$-derived ages relating to the deposition of KOT (e.g. Wilson et al., 1988; Froggatt and Lowe, 1990; Gillespie et al., 1992; Lowe et al., 2008) range from ca 20,000 to ca $25,000{ }^{14} \mathrm{C}$ yr BP. Clearly, not all can represent the age of the eruption 
(Lowe et al., 2010). Since 1988, a radiocarbon age, \pm 1 standard deviation (sd), of $22,590 \pm 230{ }^{14} \mathrm{C}$ y BP has been adopted for the KOT, based on pooled ages on four small carbonised branch fragments, collected at four separate sites, embedded within Oruanui ignimbrite emplaced during the eruption (Wilson et al., 1988). This mean radiocarbon age was calibrated by correlation to the Cariaco Basin sequence via OxCal, at 27,097 \pm 957 cal yr BP ( \pm 2 sd) (Lowe et al., 2008). The ages derived from these four samples were considered more optimal for dating the eruption event than ages from organic materials stratigraphically bracketing the tephra, or ages based on other dating techniques (Lowe et al., 2008, 2010).

Growing suspicion about whether the adopted age of KOT is accurate has arisen from (i) detailed radiocarbon chronologies from LGM lake sediments (e.g. Newnham et al., 2007a; Vandergoes et al., in this issue), and (ii) OSL ages of KOT in loess (Almond et al., 2007;
Grapes et al., 2010a, 2010b). Here we present results from recent sampling and dating of carbonised wood within the ignimbrite, intact and in situ plant remains overwhelmed by distal tephra-fall deposits, and organic material from undisturbed lake sediment enclosing the tephra layer. These samples are considered optimal to provide robust age estimates for the eruption. Using the latest ${ }^{14} \mathrm{C}$ dating methods, combined with a range of contemporary ${ }^{14} \mathrm{C}$ pre-treatments and highprecision replication, we evaluate the results using Bayesian statistical approaches that incorporate stratigraphic information (OxCal4.1.7; Bronk Ramsey, 2009a, 2009b) to quantify and reduce uncertainties.

Reviews of past dating efforts, and the rationale for the previously accepted age of the KOT, are provided by Froggatt and Lowe (1990) and Lowe et al. (2008, 2010). Our focus in this short paper is on documenting the new ${ }^{14} \mathrm{C}$ determinations and the modelling approach used to re-evaluate the age of KOT. We also discuss some

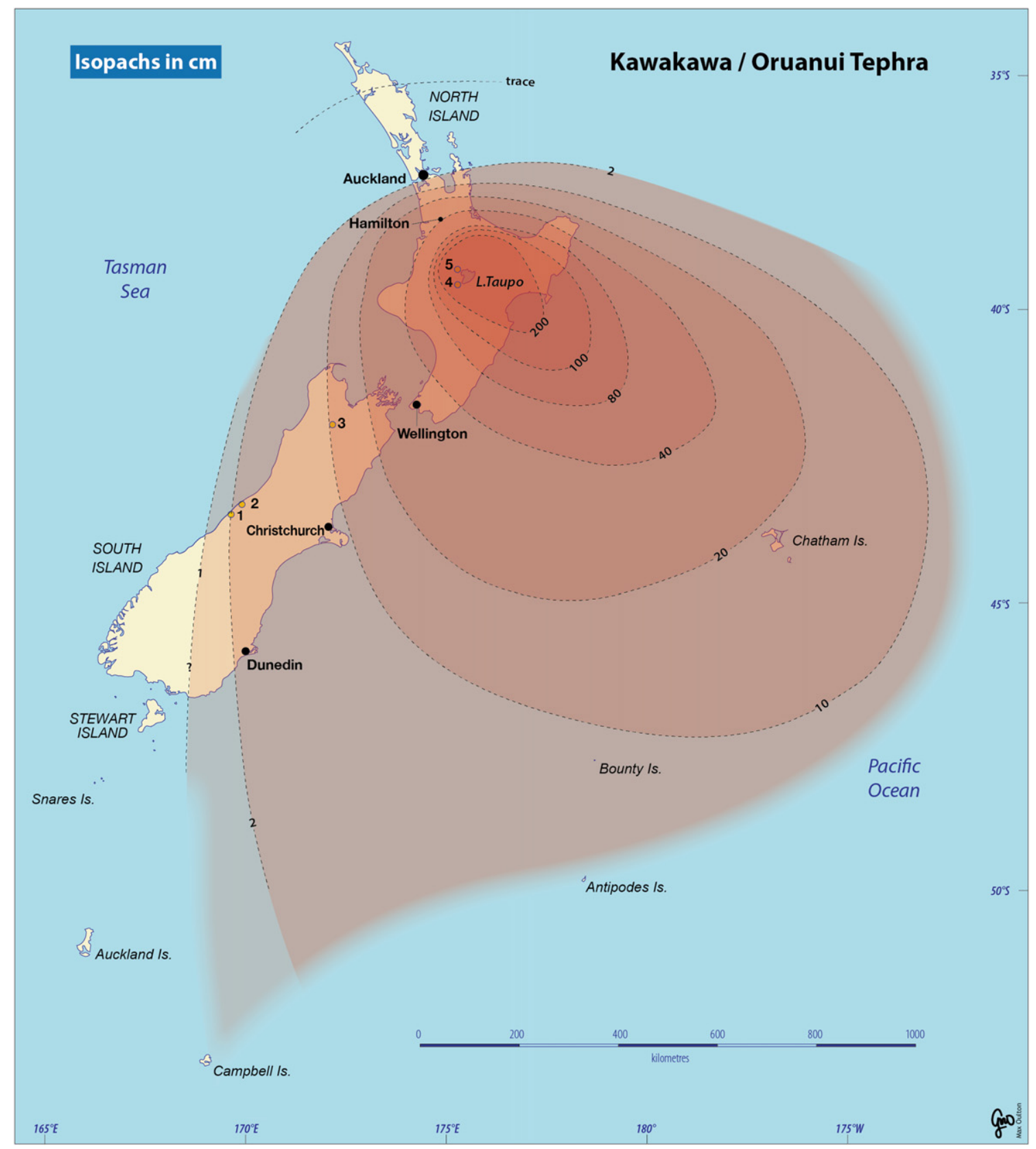


Mangatu Stream (5) sites (map modified from Lowe et al., 2008; including new data from Ryan et al., 2012). 
implications for climatic correlations locally as part of the NZINTIMATE project (Barrell et al., in this issue) and regionally in the wider southwest Pacific area.

\section{Site description}

New collections for ${ }^{14} \mathrm{C}$ dating were made at four sites containing Kawakawa/Oruanui eruptives (Fig. 1). Mangatu Stream and Taurewa south are proximal to Taupo volcano, whereas Howard valley and Galway tarn are distal tephra-fall locations some 400$700 \mathrm{~km}$ from source.

Mangatu Stream $\left(38^{\circ} 40^{\prime} 48.9^{\prime \prime} \mathrm{S}, 175^{\circ} 36^{\prime} 38 .^{\prime \prime} \mathrm{E}, 560 \mathrm{~m}\right.$ above sea level [asl]), lies $\sim 15 \mathrm{~km}$ west of Lake Taupo and is a tributary of the Waihaha River which drains to the lake. Stream incision has exposed Oruanui ignimbrite emplaced during the Oruanui eruption. Carbonised branch fragments within the ignimbrite were sampled (by C.J.N. Wilson) for dating to provide a direct age for the eruption.

At Taurewa south $\left(39^{\circ} 05^{\prime} 04.9^{\prime \prime} \mathrm{S}, 175^{\circ} 33^{\prime} 10.9^{\prime \prime} \mathrm{E}, 823 \mathrm{~m}\right.$ asl), a road cutting on the eastern side of State Highway 47 on the lower slopes of Mt Tongariro, exposes Oruanui ignimbrite overlying flattened twigs, including wood from short lived ( $<50$ years) species Hebe and Dracophyllum at the top of a pale- to dark-brown paleosol (McGlone and Topping, 1983). Twigs of these species were sampled (by M.S. McGlone) for dating to provide a direct age for the eruption.

At Howard valley in southeast Nelson $\left(41^{\circ} 46^{\prime} 38^{\prime \prime} \mathrm{S}, 172^{\circ} 39^{\prime} 43^{\prime \prime} \mathrm{E}\right.$, $480 \mathrm{~m}$ asl), an alluvial sequence exposed in a river terrace edge contains $10 \mathrm{~cm}$ of the KOT enclosed above and below by brown organic-rich silt (Campbell, 1986; Challis et al., 1994; McLea, 1996; Marra and Thackray, 2010; Callard et al., in this issue). The elemental composition of glass shards (Table S1, Supplementary data) confirms the tephra as KOT. Well-preserved heath macrofossil species (Styphelioideae), in-situ and flattened during burial by the KOT, were collected from the base of the KOT (by M.J. Vandergoes) to provide a close pre-eruption age.

Galway tarn $\left(43^{\circ} 24^{\prime} 30^{\prime \prime} \mathrm{S}, 169^{\circ} 52^{\prime} 24^{\prime \prime} \mathrm{E}, 130 \mathrm{~m}\right.$ asl $)$ is a small kettle lake formed within pre-LGM moraines (Newnham et al., 2007a). Sediment coring revealed $5.5 \mathrm{~m}$ of water and soft sediment overlying $4.3 \mathrm{~m}$ of stiff undisturbed sediment. The stiff sediment includes a 1.0-1.5-cm-thick tephra layer, $7.01 \mathrm{~m}$ below the lake surface. Identification as KOT is confirmed by glass shard

Table 1

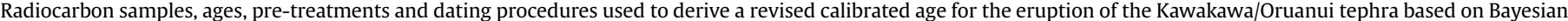
probability modelling. Calibrated eruption age in bold.

\begin{tabular}{|c|c|c|c|c|c|c|c|c|}
\hline Lab number ${ }^{a}$ & Location & Sample $^{b}$ & $\begin{array}{l}\text { Position of } \\
\text { sample } \\
\text { regarding } \\
\text { tephra }\end{array}$ & $\begin{array}{c}\text { Conventional age } \\
( \pm 1 \sigma) \\
{ }^{14} \mathrm{C} \text { yr BP }\end{array}$ & $\begin{array}{c}\text { Pre- } \\
\text { treatment/ } \\
\text { dating } \\
\text { method }^{c}\end{array}$ & $\delta^{13} \mathrm{C} \%$ & $\begin{array}{c}\text { Calibrated age range }^{d} \\
(95.4 \%) \text { cal. yr BP }\end{array}$ & $\begin{array}{c}\text { Mean calibrated } \\
\text { age }^{d}( \pm 2 \sigma) \text { cal. yr } \\
\text { BP }\end{array}$ \\
\hline OS52397 & \multirow{7}{*}{ Galway tarn } & OM-S & Above & $20,600 \pm 120$ & $\mathrm{AA}$ & -26.1 & \multirow{7}{*}{$\begin{array}{l}24,200-25,240(95.4 \%) \\
n=7, \text { post-eruption } \\
\text { boundary }\end{array}$} & \multirow{7}{*}{$24,820 \pm 580$} \\
\hline OS52347 & & LS & Above & $20,400 \pm 95$ & $\mathrm{AA}$ & -26.7 & & \\
\hline OS53989 & & LS & Above & $21,200 \pm 110$ & AA & -27.0 & & \\
\hline OS52346 & & LS & Above & $21,200 \pm 85$ & $A A$ & -26.7 & & \\
\hline OS52839 & & OM-S & Above & $20,900 \pm 190$ & AA & -27.0 & & \\
\hline OS52313 & & LS & Above & $21,600 \pm 100^{f}$ & AA & -27.0 & & \\
\hline OS52314 & & M-S & Above & $21,200 \pm 90$ & AA & -25.8 & & \\
\hline Wk21536A & \multirow{5}{*}{$\begin{array}{l}\text { Mangatu } \\
\text { Stream }\end{array}$} & $\mathrm{CB}$ & In ignimbrite & $20,990 \pm 130^{f}$ & AAR & -24.2 & \multirow{8}{*}{$\begin{array}{l}25,200-25,510(95.4 \%) \\
n=8, \text { syn-eruption }^{\mathrm{e}}\end{array}$} & \multirow{8}{*}{$\begin{array}{l}25,360 \pm 160 \\
(n=22)\end{array}$} \\
\hline Wk21536B & & $\mathrm{CB}$ & In ignimbrite & $21,300 \pm 100$ & $A A$ & -23.9 & & \\
\hline Wk29747 & & $\mathrm{CB}$ & In ignimbrite & $21,350 \pm 120$ & BSA & -23.3 & & \\
\hline Wk29748 & & $\mathrm{CB}$ & In ignimbrite & $21,350 \pm 120$ & BSA & -23.2 & & \\
\hline Wk29820 & & $\mathrm{CB}$ & In ignimbrite & $21,340 \pm 120$ & $\mathrm{BA}$ & -23.4 & & \\
\hline Wk30853 & \multirow{3}{*}{$\begin{array}{l}\text { Taurewa } \\
\text { south }\end{array}$} & WD & At base & $21,330 \pm 90$ & $\mathrm{HA}$ & -22.1 & & \\
\hline $\begin{array}{l}\text { Wk30853/U } \\
\text { Cl93056 }\end{array}$ & & WD & At base & $21,330 \pm 60$ & $A A$ & -22.1 & & \\
\hline $\begin{array}{l}\text { Wk30853/U } \\
\mathrm{Cl} 93058\end{array}$ & & WD & At base & $21,290 \pm 60$ & $\mathrm{HA}$ & -22.1 & & \\
\hline OS52640 & \multirow{6}{*}{ Galway tarn } & $M-S$ & Below & $21,500 \pm 210$ & AA & -26.7 & \multirow{7}{*}{$\begin{array}{l}25,330-25,990(95.4 \%) \\
n=7, \text { pre-eruption } \\
\text { boundary }\end{array}$} & \multirow{7}{*}{$25,620 \pm 360$} \\
\hline OS52348 & & LS & Below & $21,500 \pm 85$ & AA & -27.2 & & \\
\hline OS52396 & & LS & Below & $21,300 \pm 110$ & $A A$ & -27.0 & & \\
\hline OS52702 & & M-S & Below & $21,300 \pm 100$ & $\mathrm{AA}$ & -26.9 & & \\
\hline OS52312 & & LS & Below & $21,400 \pm 85$ & $A A$ & -27.3 & & \\
\hline OS52638 & & M-S & Below & $21,700 \pm 85$ & $\mathrm{AA}$ & -26.8 & & \\
\hline OS83042 & \multirow{2}{*}{$\begin{array}{l}\text { Howard } \\
\text { valley }\end{array}$} & M-St & Below & $21,100 \pm 110^{f}$ & AA & -22.4 & & \\
\hline OS83041 & & M-StL & Below & $18,800 \pm 100$ & $A A$ & -22.45 & \multicolumn{2}{|l|}{ Rejected as outlier } \\
\hline
\end{tabular}

\footnotetext{
${ }^{a}$ Radiocarbon laboratories: National Ocean Sciences AMS laboratory, Woods Hole Oceanographic Institution, Massachusetts, USA (OS); Waikato 2 rip If 2 ry, Hamilton, New Zealand (Wk); University of California, Radiocarbon 0 ory, Irvine, USA (UCI).

${ }^{\mathrm{b}} \mathrm{CB}$, carbonised small branch(es); LS, organic lake sediment; OM-S, matter/sphagnum; M-S, macrofossil-sphagnum; M-StL macrofossil- styphelioideae leaf fragments (mixed); M-St, macrofossil- styphelioideae complete; WD, wood.

${ }^{\mathrm{C}}$ Pre-treatment and/or dating method: $\mathrm{AAR}=\mathrm{ABA}$ radiometric; $\mathrm{BSA}=\mathrm{ABOX}-\mathrm{SC}$ AMS; $\mathrm{BA}=\mathrm{ABOX} \mathrm{AMS} ; \mathrm{AA}=\mathrm{ABA}$ AMS; HA = Holocellulose AMS.

${ }^{d}$ Calibrations were made using IntCal09 (Reimer et al., 2009) after first subtracting the Southern Hemisphere offset of $44 \pm 17$ years from ${ }^{14} \mathrm{C}$ ages (Hogg et al., 2011). The age shown in bold is the new eruption age (based on 22 ages in total) that we have determined for the tephra using Bayesian-based Tau_Boundary modelling via OxCal4.1.7. e The $8{ }^{14} \mathrm{C}$ ages from syn-eruption samples when pooled yield an error-weighted mean ${ }^{14} \mathrm{C}$ age of $21,300 \pm 120{ }^{14} \mathrm{C}$ yr $\mathrm{BP}(n=8 ; \mathrm{df}=7, \mathrm{~T}=7.2(5 \% 14.1)$, which, after subtracting the Southern Hemisphere offset, calibrates to $25,400 \pm 460$ cal yr BP ( $\pm 2 \mathrm{sd}$ ) using IntCal09 and OxCal4.1.7, in satisfactory accord with the more precise modelled calibrated age of $25,360 \pm 160 \mathrm{cal}$ yr BP $(n=22)$.

${ }^{f}$ Poor agreement warning: Samples OS52313, Wk-21536A, OS83042 show relatively poor agreement indices (14.3\%, 31.0\% and 59.9\%, respectively; Fig. S1) compared with the other ages in their groupings. Because the outlier analysis of the 22 sample data set (OS83041 omitted, see text) revealed no significant outliers, OS52313, Wk-21536A, OS83042 were included in the age modelling.
} 
chemistry (Newnham et al., 2007a). Newnham et al. (2007a) obtained mean ages from pollen and organic concentrates directly above and below the KOT ( $\pm 1 \mathrm{sd}$ ) of $21,000 \pm 170{ }^{14} \mathrm{C}$ yr BP (above, $n=6$ ) and $21,585 \pm 180{ }^{14} \mathrm{C}$ yr BP (below, $n=6$ ) (Lowe et al., 2008). Subsequently, plant macrofossils and organic sediment samples were collected (by M.J. Vandergoes) from within $5 \mathrm{~mm}$ above $(n=7)$ and below $(n=6)$ the KOT (Table 1$)$ to provide close bracketing ages for the tephra.

\section{Sample treatment, radiocarbon dating, calibration and modelling}

Samples were measured for ${ }^{14} \mathrm{C}$ using AMS analysis with duplicate conventional radiometric analysis of one sample. A range of pre-treatments was applied to the samples from Mangatu Stream, Tauwera south, and Howard valley, including acid-base-wet oxidation (ABOX) and ABOX followed by stepped combustion (ABOX-SC);

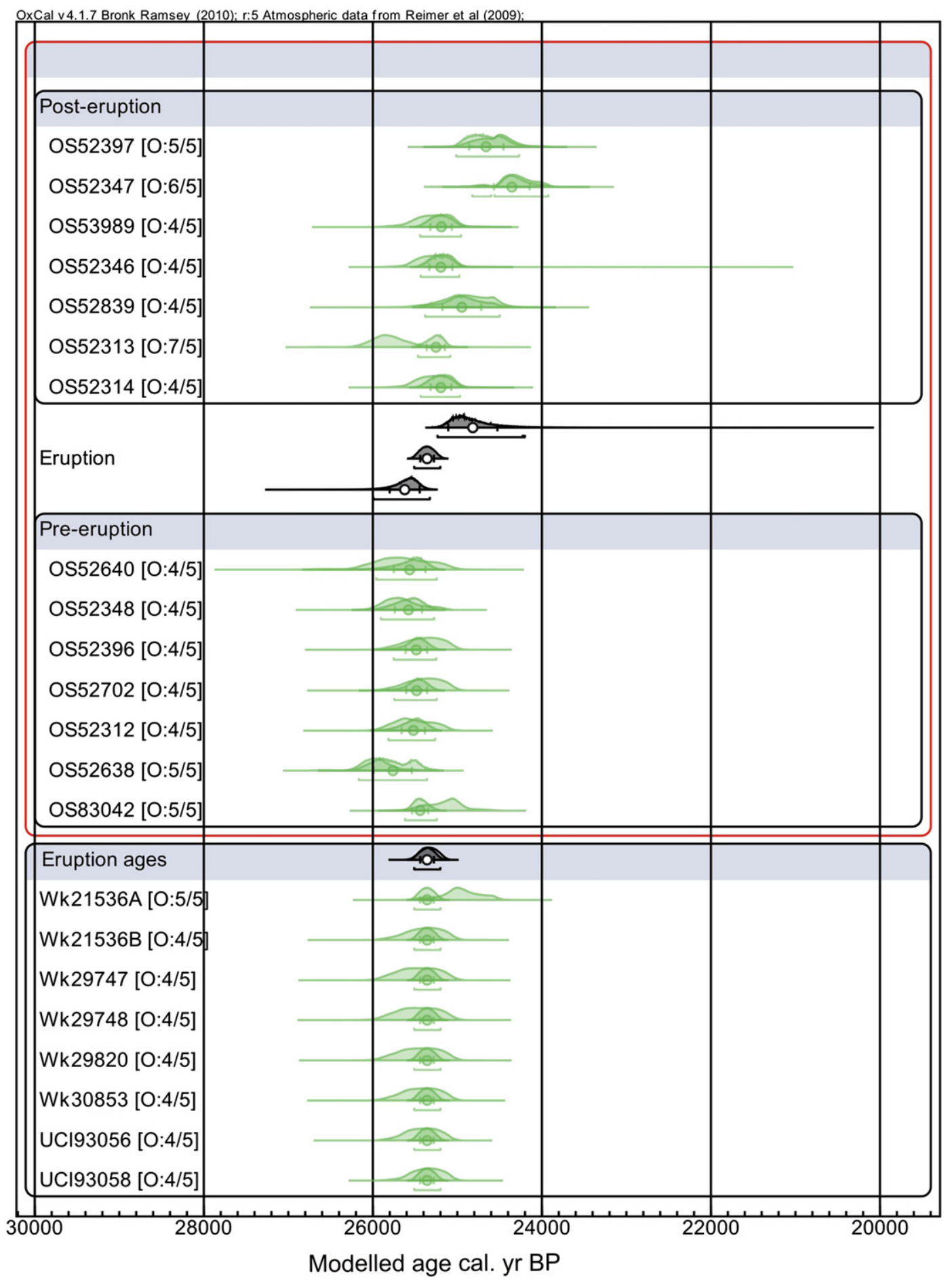



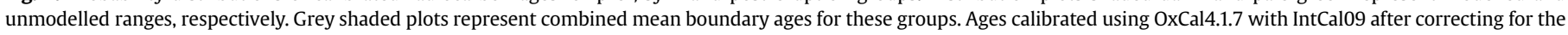
Southern Hemisphere offset (Hogg et al., 2011). (For interpretation of the references to colour in this figure legend, the reader is referred to the web version of this article.) 
acid-base-acid (ABA); and holocellulose $(\mathrm{H})$ extraction (Table 1). Samples from Galway tarn underwent ABA pre-treatment.

Measured ages in ${ }^{14} \mathrm{C}$ years are reported at $\pm 1 \mathrm{sd}$. Calibrated (calendrical) ages based on IntCal09 (Reimer et al., 2009) are expressed at $\pm 2 \mathrm{sd}$, or as a range at $95.4 \%$ confidence. A Southern Hemisphere offset of $44 \pm 17^{14} \mathrm{C}$ years was applied prior to calibration (Hogg et al., 2011). A Bayesian calibration model incorporating stratigraphic information as well as age data was developed within OxCal4.1.7 (Bronk Ramsey, 2009b). Samples were divided into three stratigraphic groups, pre-eruption, syn-eruption, or posteruption, and modelled ages to define a maximum probability age for each group were generated using the Tau_Boundary function.

\section{Results and discussion}

\subsection{Radiocarbon data}

Results from radiocarbon analyses of 23 samples associated with the Kawakawa/Oruanui eruptives from the four sites are given in Table 1. One age is rejected as an outlier (see below) and the Bayesian modelling is based on the remaining 22 ages.

Replicate dating of carbonised branches wood from within or directly below the Oruanui ignimbrite at Mangatu Stream and Taurewa south yielded internally consistent syn-eruption ages that overlap within $1 \mathrm{sd}$, ranging from $20,990 \pm 130$ to $21,350 \pm$ $120{ }^{14} \mathrm{C}$ yr BP. The calibrated age range of the syn-eruption samples is $25,200-25,510$ cal yr BP.

Samples below the KOT at Galway tarn yielded ages ranging from $21,300 \pm 110$ to $21,700 \pm 85{ }^{14} \mathrm{C}$ yr BP $(25,330-25,990$ cal yr BP $)$, whereas samples from above the KOT range from $20,400 \pm 95$ to
$21,600 \pm 100{ }^{14} \mathrm{C}$ yr BP $(24,200-25,240$ cal yr BP). These ages align closely with previous dating of these horizons (Newnham et al., 2007a; Lowe et al., 2008).

Two samples of plant macrofossils from below KOT at Howard valley provided ages of 21,100 $\pm 110\left(\right.$ OS83042) and $18,800 \pm 100{ }^{14} \mathrm{C} \mathrm{yr}$ BP (OS83041). OS83042 comprised full macrofossil remains of a lowgrowing heath, whereas OS83041 included unidentifiable leaf and plant fragments. Root material (if any) within these plant fragments may have been a source of contamination by younger carbon. In any event, OS83041 is identified as an outlier and is excluded from the modelling.

\subsection{Revised age for the KOT based on probability modelling}

Our analyses of optimal materials from positions directly above, within, or directly below Kawakawa/Oruanui eruptives at four sites provide 22 ages that consistently range between ca 20,400 and $21,700{ }^{14} \mathrm{C}$ yr BP. All are younger than the mean age of $22,590 \pm 230{ }^{14} \mathrm{C}$ yr BP derived more than 20 years ago by Wilson et al. (1988) on four carbonised branches from Oruanui ignimbrite. We have been unable to replicate the four ages of Wilson et al. (1988), even using similarly carbonised materials from Oruanui ignimbrite and, as far as we know, nothing remains of the Wilson et al. (1988) samples, so they cannot be retested. We attribute the discrepancy to methodological advances in ${ }^{14} \mathrm{C}$ pre-treatment since the 1980 s, as well as improvements in analytical protocols, sensitivity and precision, especially in regard to small-sized samples.

Table 1 and Fig. S1 present the results of age probability modelling. Outlier analysis of the full data set ( $n=22$; OS83041 omitted) identifies three ages with 'poor agreement', but not
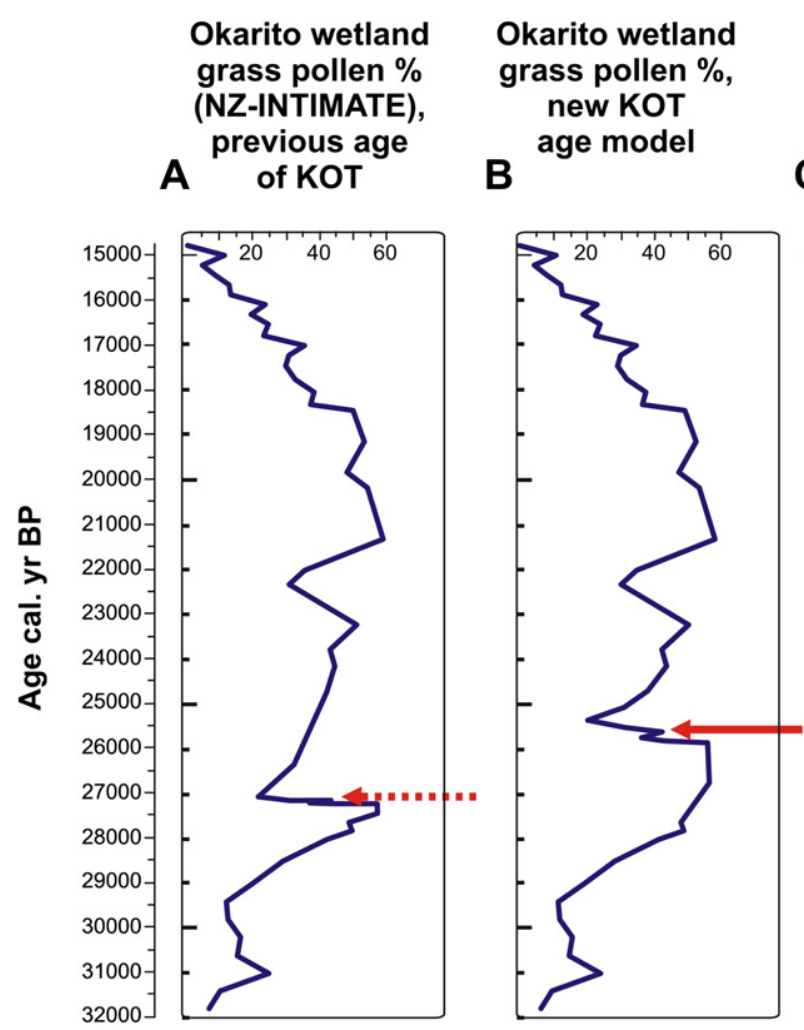

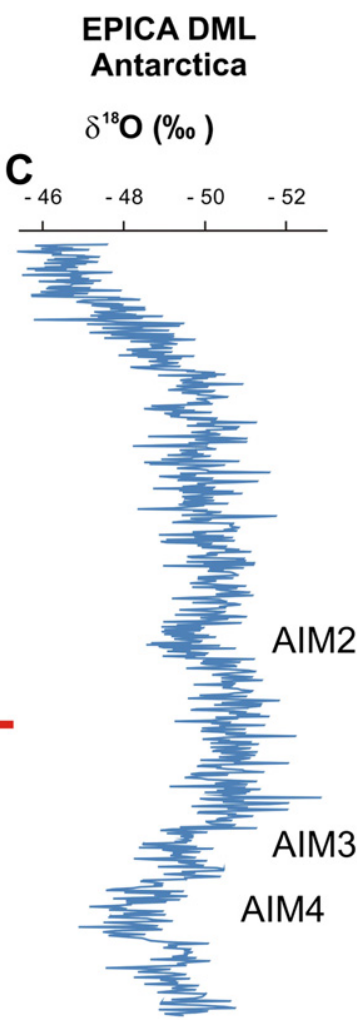

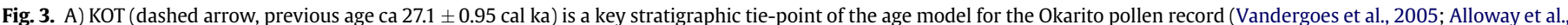

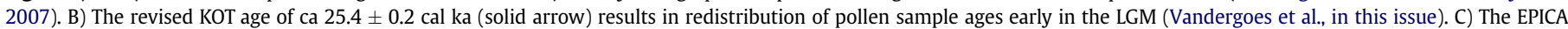



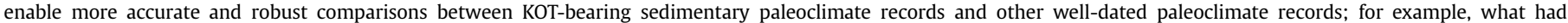


Antarctic isotopic record of the post-AIM3 stadial. 
sufficient to warrant their exclusion. Samples associated with ignimbrite emplacement at Mangatu Stream and Taurewa south are considered most appropriate to define the age of the eruption because they are proximal to source and are derived from shortlived species (in-built age $<50$ years) that underwent immediate burial. These syn-eruption ages form the group around which the pre- and post-eruption ages are centred to model the maximum probability ages for the eruption group boundaries (Table 1). On the basis of these new data we present a revised age for the KOT of $25,360 \pm 160$ cal yr BP $( \pm 2 \mathrm{sd})(n=22)$, equating to $25,200-$ 25,510 cal yr BP (Fig. 2; Fig. S1).

The revised KOT age is $\sim 1700$ cal years younger at face value than the age of $27,097 \pm 957$ cal yr BP reported by Lowe et al. (2008, 2010), following Wilson et al. (1988). The revised age remains compatible with tephrostratigraphic constraints from overlying Te Rere and Okareka tephras, dated at 25,170 \pm 960 and $21,860 \pm 290$ cal yr BP, respectively, and underlying Poihipi and Okaia tephras, ca 28,450 \pm 960 and $28,620 \pm 1430$ cal yr BP, respectively (Lowe et al., in this issue). We note, however, that the ages for the Te Rere, Poihipi and Okaia tephras are based on few samples and have large error terms (Lowe et al., in this issue).

\subsection{Wider implications}

The revised KOT age has important implications for chronologies of terrestrial and marine paleoclimate records in New Zealand and the southwest Pacific. The revision shifts the ages adopted for the timing and duration of climate events associated with the LGM (Vandergoes et al., 2005; Alloway et al., 2007; Newnham et al., 2007b, 2012; Augustinus et al., 2011; Barrell et al., in this issue). The revised KOT age will enable more accurate comparison of KOTbearing sedimentary archives with paleoclimate records that are dated independently of ${ }^{14} \mathrm{C}$ (e.g., via $\mathrm{U} / \mathrm{Th},{ }^{10} \mathrm{Be}$, or ice-core layer counting). In Fig. 3, we illustrate the effect of the revised KOT age by comparing the grass pollen record from Okarito bog (Alloway et al., 2007; Vandergoes et al., in this issue) with the EPICA DronningMaud Land (DML) $\delta^{18} \mathrm{O}$ data (EPICA, 2006). The revised KOT age shows that the first period of increased grass pollen abundance, and inferred cold glacial climate, is nearly twice as long as was previously thought, based on the previous age model (Fig. 3A-B). The revised KOT age implies that the first grass pollen maximum at Okarito bog matches more closely with the Antarctic cold maximum that followed Antarctic interstadial event AIM3 (Fig. 3C). The timing of key events and the spatial patterning of leads or lags in climate proxies are critical for distinguishing between climatic drivers, and so it is important that this revised KOT age is used in future investigations of LGM climate variability utilising records that contain the KOT.

The revised age also has implications for the estimation of marine reservoir ages and apparent ventilation ages during the LGM in the New Zealand region. For example, in the Bay of Plenty, applying the KOT error-weighted mean age of $21,300 \pm 120{ }^{14} \mathrm{C} \mathrm{yr}$ BP (Table 1, footnote), to planktonic foraminiferal age data above and below the KOT implies a surface marine reservoir age of $3280 \pm 190{ }^{14} \mathrm{C}$ yrs, in contrast to $1990 \pm 270{ }^{14} \mathrm{C}$ yrs reported by Sikes et al. (2000). Similarly, the benthic foraminiferal age data imply an apparent ventilation age of $4760 \pm 190{ }^{14} \mathrm{C}$ yr BP, rather than $3470 \pm 270{ }^{14} \mathrm{C}$ yrs calculated by Sikes et al. (2000).

\section{Conclusions}

We provide a revised age for the KOT determined by new replicate ${ }^{14} \mathrm{C}$ dating of material from plants killed by the eruption, as well as plant material deposited just before and just after the eruption, in a Bayesian framework modelled in OxCal4.1.7 using
Tau_Boundary. The revised calibrated mean age, \pm 2 sd, for the KOT is $25,360 \pm 160 \mathrm{cal} \mathrm{yr}$ BP. The KOT is a key isochron for marine and terrestrial sedimentary records in the southwest Pacific, and the revised age will enable improved comparisons of the timing of climate events within and beyond the New Zealand region, as well as allowing surface- and deep-water marine reservoir ages to be revised for the LGM.

\section{Acknowledgements}

Christopher Bronk Ramsey is thanked for his advice on using OxCal4.1.7. We also thank two anonymous reviewers and the editor Tim Barrows for useful comments. Support for this research came from the Comer Science and Education Foundation, NOAA, NSF (EAR-0902386) and the GNS Global Change with Time programme. INQUA is thanked for support of PALCOMM Project 0806 (NZINTIMATE) and SACCOM Project 0907 (INTREPID Tephra); this paper is an output of both projects.

\section{Appendix A. Supplementary data}

Supplementary data related to this article can be found at http:// dx.doi.org/10.1016/j.quascirev.2012.11.006.

\section{References}

Alloway, B.V., Lowe, D.J., Barrell, D.J.A., Newnham, R.M., Almond, P.C., Augustinus, P.C., Bertler, N., Carter, L., Litchfield, N.J., McGlone, M.S., Shulmeister, J., Vandergoes, M.J., Williams, P.W., NZ-INTIMATE members, 2007. Towards a climate event stratigraphy for New Zealand over the past 30000 years (NZ-INTIMATE project). Journal of Quaternary Science 22, 9-35.

Almond, P.C., Shanhun, F.L., Rieser, U., Shulmeister, J., 2007. An OSL, radiocarbon and tephra isochron-based chronology for Birdlings Flat loess at Ahuriri Quarry. Banks Peninsula, Canterbury, New Zealand. Quaternary Geochronology 2, 4-8.

Augustinus, P., D'Costa, D., Deng, Y., Hagg, J., Shane, P., 2011. A multi-proxy record of changing environments from ca 30000 to 9000 cal. a BP: Onepoto maar palaeolake, Auckland, New Zealand. Journal of Quaternary Science 26, 389-401.

Barrell, D.J.A., Almond, P.C., Vandergoes, M.J., Lowe, D.J., Newnham, R.M., NZ INTIMATE members. A composite pollen-based stratotype for inter-regional evaluation of climatic events in New Zealand over the past 30,000 years (NZINTIMATE project). Quaternary Science Reviews, in this issue.

Bronk Ramsey, C., 2009a. Dealing with outliers and offsets in radiocarbon dating Radiocarbon 51, 1023-1045.

Bronk Ramsey, C., 2009b. Bayesian analysis of radiocarbon dates. Radiocarbon 51, 337-360.

Campbell, I.B., 1986. New occurrences and distribution of Kawakawa Tephra in South Island, New Zealand. New Zealand Journal of Geology and Geophysics 29, 425-435

Challis, G.A., Johnston, M.R., Lauder, W.R., Suggate, R.P., 1994. Geology of the Lake Rotoroa Area, Nelson. Scale 1: 50 000, Geological Map 8. 1 sheet +32 pp. Institute of Geological and Nuclear Sciences, Lower Hutt, New Zealand.

Callard, S.L., Newnham, R.M., Vandergoes, M.J., Marra, M.J., Alloway, B.V. Palynology vegetation and climate of Howard valley, South Island, New Zealand preceding and during the Last Glacial Maximum. Quaternary Science Reviews, in this issue.

EPICA Community Members, 2006. One-to-one coupling of glacial climate variability in Greenland and Antarctica. Nature 444, 195-198.

Froggatt, P.C., Lowe, D.J., 1990. A review of late Quaternary silicic and some other tephra formations from New Zealand: their stratigraphy, nomenclature, distribution, volume, and age. New Zealand Journal of Geology and Geophysics 33, 89-109.

Gillespie, R., Hammond, A.P., Goh, K.M., Tonkin, P.J., Lowe, D.C., Sparks, R.J., Wallace, G., 1992. AMS dating of a late Quaternary tephra at Graham's Terrace, New Zealand. Radiocarbon 34, 21-27.

Grapes, R., Rieser, U., Wang, N., 2010a. Optical luminescence dating of a loess section containing a critical tephra marker horizon, SW North Island of New Zealand. Quaternary Geochronology 5, 164-169.

Grapes, R., Rieser, U., Wang, N., 2010b. Reply to Lowe, D.J., Wilson, C.J.N., Newnham, R.M., Hogg, A.G. comment on Grapes, R., Rieser, U., Wang, N., 2010. Optical luminescence dating of a loess section containing a critical tephra marker horizon, SW North Island of New Zealand. Quaternary Geochronology 5, 497-501.

Hogg, A.G., Palmer, J.G., Boswijk, G., Turney, C.S.M., 2011. High-precision radiocarbon measurements of tree-ring dated wood from New Zealand: 195 BC-AD 995. Radiocarbon 53, 529-542.

Lemieux-Dudon, B., Blayo, E., Petit, J.R., Waelbroeck, C., Svensson, A., Ritz, C., Barnola, J.M., Narcisi, B.M., Parrenin, F., 2010. Consistent dating for Antarctic and Greenland ice cores. Quaternary Science Reviews 29, 8-20. 
Lowe, D.J., Shane, P.A.R., Alloway, B.V., Newnham, R.M., 2008. Fingerprints and age models for widespread New Zealand tephra marker beds erupted since 30,000 years ago: a framework for NZ-INTIMATE. Quaternary Science Reviews 27, 95-126.

Lowe, D.J., Wilson, C.J.N., Newnham, R.M., Hogg, A.G., 2010. Dating the Kawakawa/ Oruanui eruption: comment on "Optical luminescence dating of a loess section containing a critical tephra marker horizon, SW North Island of New Zealand" by R. Grapes et al. Quaternary Geochronology 5, 493-496.

Lowe, D.J., Blaauw, M., Hogg, A.G., Newnham, R.M. Ages of 24 widespread tephras erupted since 30,000 years ago in New Zealand, with re-evaluation of the timing and palaeoclimatic implications of the late-glacial cool episode at Kaipo bog. Quaternary Science Reviews, in this issue.

McGlone, M.S., Topping, W.W., 1983. Late Quaternary vegetation, Tongariro region, central North Island, New Zealand. New Zealand Journal of Botany 21, 53-76.

McLea, W.L., 1996. The late-Quaternary pollen record of south-east Nelson, South Island, New Zealand. New Zealand Journal of Botany 34, 523-538.

Marra, M.J., Thackray, G.D., 2010. Glacial forest refugium in Howard valley, South Island, New Zealand. Journal of Quaternary Science 25, 309-319.

Newnham, R.M., Vandergoes, M.J., Garnett, M.H., Lowe, D.J., Prior, C., Almond, P.C. 2007a. Test of AMS ${ }^{14} \mathrm{C}$ dating of pollen concentrates using tephrochronology. Journal of Quaternary Science 22, 37-51.

Newnham, R.M., Lowe, D.J., Giles, T., Alloway, B.V., 2007b. Vegetation and climate of Auckland, New Zealand, since ca 32000 cal. yr ago: support for an extended LGM. Journal of Quaternary Science 22, 517-534.

Newnham, R.M., Vandergoes, M.J., Sikes, E., Carter, L., Wilmshurst, J.M. Lowe, D.J., McGlone, M.S., Sandiford, A., 2012. Does the bipolar seesaw extend to the terrestrial southern mid-latitudes? Quaternary Science Reviews 36, 214-222.

Pillans, B.J., McGlone, M.S., Palmer, A.S., Mildenhall, D.C., Alloway, B.V., Berger, G.W., 1993. The Last Glacial Maximum in central and southern North Island, New Zealand: a palaeoenvironmental reconstruction using the Kawakawa Tephra Formation as a chronostratigraphic marker. Palaeogeography, Palaeoclimatology, Palaeoecology 101, 283-304.

Reimer, P.J., Baillie, M.G.L., Bard, E., et al., 2009. IntCal09 and Marine09 radiocarbon age calibration curves, $0-50,000$ years cal BP. Radiocarbon 51, 1111-1150.

Ryan, M.T., Dunbar, G.B., Vandegoes, M.J., Neil, H.L., Hannah, M.J., Newnham, R.M., Bostock, H., Alloway, B.V., 2012. Vegetation and climate in Southern Hemisphere mid-latitudes since $210 \mathrm{ka}$ : new insights from marine and terrestrial pollen records from New Zealand. Quaternary Science Reviews 48, 80-98.

Sikes, E.L., Samson, C.R., Guilderson, T.P., Howard, W.R., 2000. Old radiocarbon ages in the southwest Pacific Ocean during the Last Glacial period and deglaciation. Nature 405, 555-559.

Vandergoes, M.J., Newnham, R.M., Preusser, F., Hendy, C.H., Lowell, T.V., Fitzsimons, S.J., Hogg, A.G., Kasper, H.U., Schlüchter, C., 2005. Regional insolation forcing of late Quaternary climate change in the Southern Hemisphere. Nature 436, 242-245.

Vandergoes, M.J., Newnham, R.M., Denton, G.H., Blaauw, M., Barrell, D.J.A. The anatomy of Last Glacial Maximum climate change in the southern mid-latitudes derived from pollen records in south Westland, New Zealand, in this issue.

Wilson, C.J.N., 2001. The 26.5 ka Oruanui eruption, New Zealand: an introduction and overview. Journal of Volcanology and Geothermal Research 112, 133-174.

Wilson, C.J.N., Switsur, R.V., Ward, A.P., 1988. A new ${ }^{14} \mathrm{C}$ age for the Oruanui (Wairakei) eruption, New Zealand. Geological Magazine 125, 297-300. 